\title{
The future of medical education in neonatology, paediatrics and paediatric virology: An interview with Professor Alan Michael Weindling, Professor of Perinatal Medicine at the University of Liverpool
}

\author{
IOANNIS N. MAMMAS and DEMETRIOS A. SPANDIDOS \\ Department of Clinical Virology, School of Medicine, University of Crete, Heraklion 71003, Greece
}

Received June 22, 2018; Accepted July 23, 2018

DOI: 10.3892/etm.2018.6547

\begin{abstract}
Professor Alan Michael Weindling, Emeritus Professor of Perinatal Medicine at the University of Liverpool in the UK, is one of the pioneers of modern neonatal care worldwide with an enormous contribution to the care of premature babies in the city of Liverpool. During the last 3 decades, his contributions focused on the development of the clinical service, the training provided and the strong research achievements at Liverpool Women's Hospital NHS Trust, one of the most widely respected centres for neonatal medicine in western Europe. According to Professor Weindling, teaching a commitment to continuing lifelong learning as well as trying to make clinical care cost-effective is really important. He highlights the value of humility, holistic scientific approach, evidence-based medicine and multidisciplinary team working to neonatal and paediatric care. Looking back to neonatology as practiced in the 1990s, he accepts that since then, the overall standard of care has improved enormously. He supports that further neonatal care research is required for the prevention and treatment of acquired brain damage as well as on looking at ways of minimising stress for families, who have a child in an intensive care unit. He could see how for most trainees a module or series of lectures in paediatric infectious diseases would be helpful as part of their training and he estimates that in the future paediatric virology may become a specialist interest for a limited number of paediatric trainees. In the context of the '4th Workshop on Paediatric Virology', which will be held in Athens, Greece, on September 22nd, 2018, Professor Weindling will receive the '2018 Paediatric Virology Award in Neonatology and Medical Education'.
\end{abstract}

Correspondence to: Professor Demetrios A. Spandidos, Department of Clinical Virology, School of Medicine, University of Crete, Heraklion 71003, Greece

E-mail: spandidos@spandidos.gr

Key words: neonatology, paediatrics, paediatric virology, medical education, Professor Alan Michael Weindling, University of Liverpool

\section{Contents}

1. Introduction

2. Questions and Answers

\section{Introduction}

Professor Alan Michael Weindling (Fig. 1), Emeritus Professor of Perinatal Medicine at the University of Liverpool in the UK, is an honorary consultant neonatologist at the tertiary neonatal intensive care unit at Liverpool Women's Hospital NHS Trust in Liverpool. He studied medicine at the University of London at Guy's Hospital in London. During his undergraduate medical studies he took a degree course in physics-in-medicine, where he became interested in medical ultrasound; he qualified with a first class honours degree in 1971 and qualified in medicine in 1974. After junior posts in London that included a post in neonatal medicine at Queen Charlottes Hospital for Women, and a post at Great Ormond Street Hospital for Sick Children, he was a registrar in paediatrics in Oxford and then became a research fellow in the Department of Paediatrics at the University of Oxford from 1980 until 1983, where his mentor was Professor Sir Peter Tizard. His thesis was on the study of cerebral haemodynamics using electrical impedance plethysmography (1). He was appointed senior lecturer in Liverpool in 1985, promoted to reader in 1991 and to professor in 1998.

Professor Weindling's scientific interest is in the transition from intra-to-extra-uterine life. In 1993, he studied medical ethics at the University of Keele, where his dissertation was into the changing the moral status of the developing human from conceptus to infancy (2). He has a particular interest in the prevention and treatment of acquired brain damage and into tissue oxygenation. He has published over 150 articles in peer-reviewed journals (3-28) and seven chapters in books. His recent book entitled 'Neonatology: A practical approach to neonatal diseases' (29) provides the scientific community with the state-of-the-art on modern neonatal care.

Professor Weindling was the Royal College of Paediatrics and Child Health (RCPCH)'s officer for continuing professional development and a member of its Council and Executive 
Committee from 1998 until 2003. From 2003 until 2008, he was chair of the UK's national Confidential Enquiry into Maternal and Childhood Deaths (CEMACH). From 2006 until his retirement in 2013, he was head of the Liverpool Postgraduate School of Paediatrics, Mersey Deanery. From 2009 until 2013, he was director of graduate studies in the Department of Women's and Children's Medicine at the Institute of Translational Medicine of the University of Liverpool. He is an honorary fellow of the Polish Neonatal Society; he was visiting Professor at Case Western Reserve University, Cleveland, Ohio, USA; he is a fellow of the Royal College of Physicians (RCP) and of the RCPCH and an honorary fellow of the Royal College of Anaesthetists; he is the founder, chair and now patron of a Liverpool charity the Newborn Appeal; he is an honorary member of the UK's Neonatal Society and of the British Association of Perinatal Medicine. He is an Associate Editor of Acta Paediatrica.

To date, Professor Weindling has helped and supported the Paediatric Virology Study Group (PVSG) since its birth (30) and has been member of its academic advisory board. In 2016, Professor Weindling was included in the seven international experts on neonatology, paediatrics, paediatric infectious diseases and virology, who commented on the debate 'paediatric virology as a new paediatric subspecialty' (31). He has also evaluated all material of the previous workshops on paediatric virology organised by the PVSG (32-34). In the context of the '4th Workshop on Paediatric Virology', which will be held in Athens, Greece, on September 22nd, 2018, Professor Weindling will receive the '2018 Paediatric Virology Award in Neonatology and Medical Education' for his outstanding academic, clinical, research and publishing contribution on neonatology and medical education.

\section{Questions and Answers}

Question: How did you become interested in medicine and later on in neonatology?

Answer: I became interested in a career in medicine while at school. For me, it was a rather natural choice; both my father and my grandfather had been doctors. My father qualified in medicine at the University of Vienna and my grandfather was an army surgeon. My interest in paediatrics arose as a medical student when I was based in Ipswich. A baby was born with spina bifida, this was before prenatal diagnosis, and the consultant paediatrician, Dr Christopher Nourse, involved the whole family in making the decision about whether to transfer for surgery. I thought that this level of care, where a truly holistic approach was taken, was marvellous and a standard that I wanted to emulate. I became interested in neonatology when I did my first post in neonatal medicine at Queen Charlotte's Hospital in London and I was very much influenced by the caring and humanistic approach of Dr David Harvey. I was impressed by an attention to medicine that was based on evidence, an understanding of physiology and the way that this could be practically applied to the patients (and their families) for whom one had responsibility. This was reinforced by another great influence, Professor Sir Peter Tizard at Oxford. The fourth person who influenced me very much was my consultant colleague at Liverpool Women's Hospital, Professor Richard Cooke. Richard was also a great

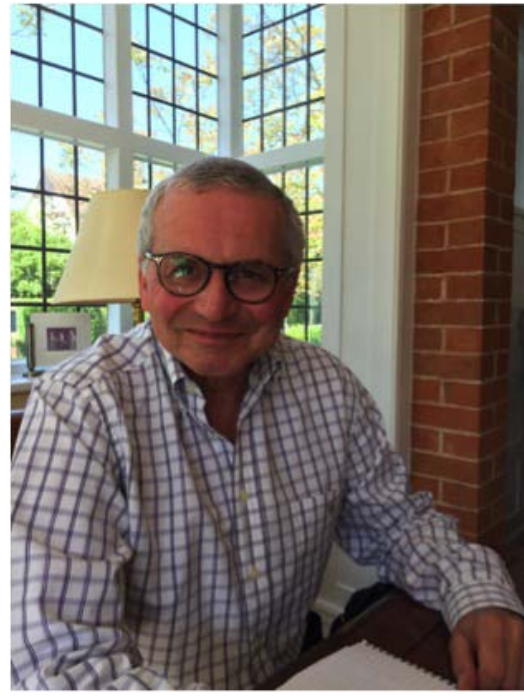

Figure 1. Professor Alan Michael Weindling, Emeritus Professor of Perinatal Medicine at the University of Liverpool (UK) and recipient of the '2018 Paediatric Virology Award in Neonatology and Medical Education'.

proponent of evidence-based medicine, always questioning and a great scientist. It was from him that I learnt that science meant knowledge. We agreed, when I was appointed that we would try to offer similar care whichever of us was on duty and that if there was ever a situation where we could not agree, we would try to resolve it by a scientific approach.

Question: You have been Professor of Perinatal Medicine at Liverpool Women's, one of the most widely respected and busiest centres for neonatal medicine in western Europe. How difficult was this, indeed?

Answer: I was very fortunate to find myself working with a great team of nurses and nurse practitioners, midwives and doctors. This team approach was one that I tried to teach.

Question: What was the most important virtue in your scientific career?

Answer: The ability to ask the question 'Why?'. And trying to use science to answer practical clinical questions, always trying to make a positive difference.

Question: You are one of the pioneers of modern neonatal care in the UK and worldwide with an enormous contribution to the care of premature babies in the city of Liverpool. Your contributions focused on the development of the clinical service, the training provided and the strong research achievements on the unit. Among these, which one do you consider as the most significant?

Answer: I think that an integrated approach is important and this is what we tried to achieve in Liverpool. Nurses and doctors at Liverpool accepted the importance of a scientific approach, which allowed us to carry out studies in the clinical environment.

Question: The University of Liverpool School of Medicine is one of the leading medical schools in the UK providing a large concentration of medical expertise in the UK, state-of-the-art-knowledge, use of new technologies and 
emphasis to international relationships and collaborations. What are the recent challenges in medical education?

Answer: The importance of realizing that it is just not possible to know everything, and that continuing learning is important: Teaching a commitment to 'lifelong learning'. A challenge is trying to make clinical care cost-effective and working in an environment where one is always conscious of limited resources. I am sure that this is an experience of clinicians not only in the UK.

Question: As a consultant neonatologist, you have been credited with the training of many leading paediatricians, neonatologists and neonatal nurses throughout the NHS as well as abroad. What is your advice for paediatric trainees, who are just starting in our field?

Answer: Remember humility, the importance of an holistic approach to care, and its scientific basis.

Question: We read you conclusion in Pediatrics: 'Our findings suggest an association between quality of neonatal care and neonatal deaths, most marked for early thermal care and ventilatory and cardiovascular support' (18). How different is indeed nowadays neonatology compared to neonatology of the 1990s, 30 years ago?

Answer: The overall standard of care has improved enormously. The establishment of standards and continuously auditing practice against these standards has been most useful. I think that limiting junior doctors' hours has been a great help, although it raises some problems of its own. The appointment of additional consultants has also been beneficial; there were two consultant neonatologists at Liverpool Women's Hospital 30 years ago, now there are eight.

Question: In one of your articles in Acta Paediatrica (5), we read about the differences in brain imaging of infants born extremely prematurely compared to those born at term. How difficult is it for neonatologists to interpret correctly these differences into their clinical practice?

Answer: Clinicians rely on the expert interpretation of specialist investigations like imaging. However, neonatologists have to be aware of the experience of the person doing the reporting; I was once told by a wise clinician, 'Musical instruments are only as good as the musician who plays them'. Some of the greatest influences in imaging (by ultrasound and magnetic resonance) have been when neonatologists themselves have undertaken the interpretation of the findings, i.e. the clinicians who have a good understanding of the baby's general clinical condition.

Question: During my time in Merseyside, I had the chance to get involved in the human bank milk in Chester. How significant is indeed the role of human breast milk in preterm neonates?

Answer: Very important. It is also important to understand that while breast milk is most appropriate for babies born at term, those born prematurely need nutritional supplements.

Question: This year is the 100 years anniversary from the Spanish influenza's outbreak in 1918 (35). As paediatric health professionals, how prepared are we for a future pandemic?
Answer: Those who work in developing countries may be, but most paediatric health professionals probably are not. Consider how long it took clinicians to appreciate the nature of the AIDS and therefore its best treatment and management.

Question: You have always shown a great interest in the families of the babies you have cared for and recognised the challenges they face. Were there moments in your career when evidence-based medicine was towards humanitarianism? What were your decisions in these challenges?

Answer: I think it is enormously important for clinicians not to lose sight of the fact that they are responsible for the care and wellbeing of small humans, who have loving families and a place in society.

Question: You have played an important part as a principal researcher in improving our understanding of the problems faced by newborn babies and their treatments. What still needs to be done in the field of neonatal care research?

Answer: There are three important areas. Firstly, further work on the prevention and treatment of acquired brain damage. The acquisition of brain damage may be through environmental effects, including infection, as well as hypoxic ischaemia. Secondly, minimising the stress to families of having a child in an intensive care unit, which is tremendously upsetting and stressful for families. Thirdly, improving postnatal nutrition, particularly for those born small and prematurely.

Question: During our previous workshops on paediatric virology we had the chance to discuss the need of subspecialty training in neonatal and paediatric viral infections $(32-34,36)$. Since this subspecialty is not recognised yet in Europe, I would appreciate your expert opinion. Do you consider training in virology as a useful tool for neonatologists and general paediatricians? Could paediatric virology be separated from paediatric infectious diseases due to the increased changes in the field of molecular virology? Could paediatric virology be a new subspecialty in the future?

Answer: I am not sure that I am the best person to answer your question. However, my view is that it is certainly beneficial of all paediatricians to have a good knowledge of virology; the two recent heath crises, ebola and zika, are clear examples. I could see how for most trainees a module or series of lectures in paediatric infectious diseases would be helpful as part of their training. For some, a higher diploma or Master's degree might be appropriate. For a very few, I could see that specialising in paediatric virology might be really helpful. However, this would be highly specialised and the specialist skills and knowledge are exemplified by the remarkable speed with which a possible vaccine to the pika virus has been taken to a preliminary trial phase.

Question: Based on your experience as the head of the Postgraduate School of Paediatrics in Liverpool, how difficult or how possible do you consider paediatric virology to be officially recognised as a separate paediatric subspecialty in the future?

Answer: It is likely that academic clinicians will develop subspecialty interests, e.g. neonatal endocrinology, cardiology, nutrition, infection. Without any doubt, paediatric virology 
may become in the future a specialist interest of a specialist in perinatal (or neonatal) infectious diseases.

Question: Professor Weindling thank you for this great honour, your inspirational answers and your valuable support to our scientific attempt.

\section{References}

1. Weindling AM: The study of cerebral haemodynamics using electrical impedance plethysmography (Doctoral Thesis). University of London, 1987.

2. Weindling AM: The changing the moral status of the developing human from conceptus to infancy. University of Keele, 1993.

3. Costeloe K, Hardy P, Juszczak E, Wilks M and Millar MR; Probiotics in Preterm Infants Study Collaborative Group: Bifidobacterium breve BBG-001 in very preterm infants: A randomised controlled phase 3 trial. Lancet 387: 649-660, 2016.

4. Szczapa T, Karpiński Ł, Moc zko J, Weindling M, Kornacka A Wróblewska K, Adamczak A, Jopek A, Chojnacka K and Gadzinowski J: Comparison of cerebral tissue oxygenation values in full term and preterm newborns by the simultaneous use of two near-infrared spectroscopy devices: An absolute and a relative trending oximeter. J Biomed Opt 18: 87006, 2013.

5. Weindling M: Insights into early brain development from modern brain imaging and outcome studies. Acta Paediatr 99: 961-966, 2010 .

6. Weindling $\mathrm{M}$ and Paize F: Peripheral haemodynamics in newborns: Best practice guidelines. Early Hum Dev 86: 159-165, 2010.

7. Azzopardi DV, Strohm B, Edwards AD, Dyet L, Halliday HL, Juszczak E, Kapellou O, Levene M, Marlow N, Porter E, et al; TOBY Study Group: Moderate hypothermia to treat perinatal asphyxial encephalopathy. N Engl J Med 361: 1349-1358, 2009.

8. Strohm B and Azzopardi D; UK TOBY Cooling Register Study Group: Temperature control during therapeutic moderate whole-body hypothermia for neonatal encephalopathy. Arch Dis Child Fetal Neonatal Ed 95: F373-F375, 2010.

9. Azzopardi D, Strohm B, Edwards AD, Halliday H, Juszczak E, Levene M, Thoresen M, Whitelaw A and Brocklehurst P; Steering Group and TOBY Cooling Register participants: Treatment of asphyxiated newborns with moderate hypothermia in routine clinical practice: How cooling is managed in the UK outside a clinical trial. Arch Dis Child Fetal Neonatal Ed 94: F260-F264, 2009.

10. Glenn S, Cunningham C, Poole H, Reeves D and Weindling M: Maternal parenting stress and its correlates in families with a young child with cerebral palsy. Child Care Health Dev 35: 71-78, 2009.

11. Pichler G, Wolf M, Roll C, Weindling MA, Greisen G, Wardle SP, Zaramella P, Naulaers G, Pellicer A, Austin T, et al: Recommendations to increase the validity and comparability of peripheral measurements by near infrared spectroscopy in neonates. 'Round table', section of haematology, oxygen transport and microcirculation, 48th annual meeting of ESPR, Prague 2007. Neonatology 94: 320-322, 2008.

12. Weindling $M$ : Nose bleeds, child protection and the difficulties faced by paediatricians. Acta Paediatr 97: 1318-1320, 2008.

13. Weindling M: Gross motor functional abilities and periventricular leukomalacia. Dev Med Child Neurol 50: 647, 2008.

14. Valls-I-Soler A, Carnielli V, Claris O, de la Cruz Bértolo J, Halliday HL, Hallman M, Hummler $\mathrm{H}$ and Weindling $\mathrm{M}$; Scientific Steering Committee von EuroNeoStat (siehe Anhang), [EuroNeoStat: a European information system on the outcomes of care for very-low-birth-weight infants $(<1500 \mathrm{~g})$ ]. Z Geburtshilfe Neonatol 212: 116-118, 2008 (In German).

15. Acolet D, Jelphs K, Davidson D, Peck E, Clemens F, Houston R, Weindling M, Lavis J and Elbourne D: The BLISS cluster randomised controlled trial of the effect of 'active dissemination of information' on standards of care for premature babies in England (BEADI) study protocol [ISRCTN89683698]. Implement Sci 2: 33, 2007.

16. Valls-i-Soler A, Carnielli V, Claris O, de la Cruz Bértolo J, Halliday HL, Hallman M, Hummler $\mathrm{H}$ and Weindling $\mathrm{M}$; Scientific Steering Committee of EuroNeoStat: EuroNeoStat: A European information system on the outcomes of care for very - low-birth-weight infants. Neonatology 93: 7-9, 2008.
17. Naulaers G, Meyns B, Miserez M, Leunens V, Van Huffel S, Casaer P, Weindling $M$ and Devlieger $H$ : Use of tissue oxygenation index and fractional tissue oxygen extraction as non-invasive parameters for cerebral oxygenation. A validation study in piglets. Neonatology 92: 120-126, 2007.

18. Acolet D, Elbourne D, McIntosh N, Weindling M, Korkodilos M, Haviland J, Modder J and Macintosh M; Confidential Enquiry Into Maternal and Child Health: Project 27/28: Inquiry into quality of neonatal care and its effect on the survival of infants who were born at 27 and 28 weeks in England, Wales, and Northern Ireland. Pediatrics 116: 1457-1465, 2005.

19. Bramwell R and Weindling M; FVWR Research Team: Families' views on ward rounds in neonatal units. Arch Dis Child Fetal Neonatal Ed 90: F429-F431, 2005.

20. Hesseling M, Weindling $M$ and Neal T: First reported use of caspofungin in an extremely low-birth-weight neonate. J Matern Fetal Neonatal Med 14: 212, 2003

21. Eisenhut M, Weindling M and Fryer A: Amyoplasia associated with a balanced de novo insertion of a segment of the long arm of chromosome 5 into chromosome 2. Am J Med Genet 107: 337-339, 2002.

22. Laws DE, Morton C, Weindling M and Clark D: Systemic effects of screening for retinopathy of prematurity. Br J Ophthalmol 80: 425-428, 1996.

23. Weindling M: Periventricular haemorrhage and periventricular leukomalacia. Br J Obstet Gynaecol 102: 278-281, 1995.

24. Marlow N, Weindling $M$ and Shaw B: Opiates, catecholamine concentrations, and ventilated preterm babies. Lancet 342 : 997-998, 1993

25. Shaw N, Gill B, Weindling $M$ and Cooke R: The changing incidence of chronic lung disease. Health Trends 25: 50-53, 1993.

26. Mathai M, Skinner A, Lawton K and Weindling M: Influence of exposure to tobacco smoke on serum alpha fetoprotein levels of women in midtrimester pregnancy. Indian J Med Res 96: 279-281, 1992.

27. Garden AS, Griffiths R, Weindling $M$ and Martin P: Magnetic resonance imaging (MRI) in obstetrics. II. Fetal anatomy. Br J Obstet Gynaecol 95: 635-636, 1988.

28. Haitas B, Barnes A, Shogry ME, Weindling M, Rolfe P and Turner RC: Delayed vascular reactivity to ischemia in diabetic microangiopathy. Diabetes Care 7: 47-51, 1984.

29. Buonocore G, Bracci R and Weindling M (eds): Neonatology: A Practical Approach to Neonatal Diseases. Springer, Verlag, 2012.

30. Mammas IN, Theodoridou $M$ and Spandidos DA: The development of the Paediatric Virology Study Group: Ten years in the making. Exp Ther Med 13: 363, 2017.

31. Mammas IN and Spandidos DA: The subspecialty of Paediatric Virology: A 'mosaic tile' in future Paediatrics. Exp Ther Med 12: 539-540, 2016

32. Mammas IN, Greenough A, Theodoridou M, Kramvis A Christaki I, Koutsaftiki C, Koutsaki M, Portaliou DM, Kostagianni G, Panagopoulou $\mathrm{P}$, et al: Current views and advances on Paediatric Virology: An update for paediatric trainees. Exp Ther Med 11: 6-14, 2016.

33. Mammas IN, Theodoridou M, Kramvis A, Thiagarajan P, Gardner S, Papaioannou G, Melidou A, Koutsaki M, Kostagianni G, Achtsidis V, et al: Paediatric Virology: A rapidly increasing educational challenge. Exp Ther Med 13: 364-377, 2017.

34. Mammas IN, Greenough A, Theodoridou M, Kramvis A, Rusan M, Melidou A, Korovessi P, Papaioannou G, Papatheodoropoulou A, Koutsaftiki C, et al: Paediatric Virology and its interaction between basic science and clinical practice (Review). Int J Mol Med 41: 1165-1176, 2018.

35. Mammas IN, Theodoridou M and Spandidos DA: The 1918 Spanish flu outbreak that devastated a Greek island underlines past lessons that must never be forgotten. Acta Paediatr: Mar 31, 2018 (Epub ahead of print).

36. Mammas IN, Greenough A, Theodoridou M and Spandidos DA: Paediatric Virology: A new paediatric subspecialty? A proposal at the Workshop on Paediatric Virology, Athens, October 10, 2015. Exp Ther Med 11: 3-5, 2016.

This work is licensed under a Creative Commons Attribution-NonCommercial-NoDerivatives 4.0 International (CC BY-NC-ND 4.0) License. 